Jurnal At-Tibyan: Jurnal Ilmu Alqur'an dan Tafsir

Volume 6 No. 2, Desember 2021 (p. 301-322)

P ISSN 2442-594X | E ISSN 2579-5708

http://journal.iainlangsa.ac.id/index.php/tibyan

\title{
THE RELEVANCE OF ODD-EVEN VERSES IN THE QUR'ĀN WITH MATHEMATICS EDUCATION
}

\author{
Agus Mistakus Surur \\ Institut Agama Islam Negeri Kediri, Indonesia \\ surur.math@gmail.com \\ Sri Pujilestari \\ Universitas Islam Negeri Maulana Malik Ibrahim Malang, Indonesia \\ lestari.elsurury@gmail.com \\ \begin{tabular}{|l|l|l|}
\hline \multicolumn{2}{|c|}{ DOI 10.32505/at-tibyan.v6i2.3284 } \\
\hline Submitted: 15-09-2021 & Revised: 18-12-2021 & Accepted: 21-12-2021 \\
\hline
\end{tabular}
}

\begin{abstract}
Education is an effort to improve knowledge, one of which is by conducting studies on the Qur'an and Mathematics. This research examines the verses of the Qur'an containing odd-even concepts and their relevance to mathematics. By using the library research method, the verse selection step is taken from observations of the translated Qur'an. The mathematical concepts found are materials related to odd-even concepts, such as KPK (Least Common Multiple) and FPB (Greatest Common Factor), Venn diagrams, and Phi in tawāf. As the result, the number of verses and the number of surahs show odd-even numbers. If the numbers are added up to 38 , these will be equal to the number of letters in the syahädah sentence.
\end{abstract}

Keywords: Odd-Even concepts, The Qur'an, Mathematics

\begin{abstract}
Abstrak
Pendidikan adalah upaya untuk meningkatkan ilmu-pengetahun, salah satunya dengan melakukan pengkajian tentang Al-Qur'an dan Matematika. Penelitian ini mengkaji tentang ayat-ayat al-Qur'an yang memiliki konsep ganjil-genap dan relevansinya dengan ilmu matematika. Dengan menggunakan metode kepustakaan, tahap seleksi ayat diambil dari hasil pengamatan terhadap alQur'an terjemah. Konsep matematika yang ditemukan adalah materi-materi yang berkaitan dengan konsep ganjil-genap, seperti KPK-FPB, Diagram Venn, dan Phi dalam țawāf. Hasil penelitian menunjukkan bahwa jumlah ayat dan jumlah angka surat memperlihatkan angka ganjil-genap. Bila angka-angka ini dijumlahkan menjadi 38, maka angka ini sesuai dengan jumlah huruf dalam kalimat Syahadat.
\end{abstract}

Kata Kunci: Ganjil, Genap, Al-Qur'an, Matematika

Copyright @ 2021. Owned by the Author, published by Jurnal At-Tibyan: Jurnal Ilmu Alqur'an dan Tafsir. Articles with open access. License: CC-BY 


\section{Introduction}

The integration of interconnections between sciences or what is often referred to as multi-disciplinary is something that needs to be pursued. The integration model of mathematics and the Qur'an is expected to provide insight and reference to be applied in learning practice ${ }^{1}$. As in education, the linkages between materials, between subjects and in lectures between courses, there is a link between them. This connection will make what is learned meaningful. In addition to the relationship between the two, it can also be connected with culture. The model for integrating mathematics with Islamic values and cultural local wisdom is to make the Qur'an and cultural local wisdom a source of mathematical knowledge, expand the study of mathematical characteristics in the Qur'an and local culture, make Islamic culture a mathematics library, and foster the ulul albab's personal character that local cultural wisdom².

Learning will also be easy for students to follow if the basic lessons to be studied have been mastered (at least students have already obtained it). The expansion of this prerequisite material will make it easier for students to solve problems that have high complexity ${ }^{3}$. The location of the previous material is a prerequisite for learning new things. There is a link between the previous material and what will be studied, so that there is a connection between previous learning and current learning. There is an influence between mastery of prerequisite material and mathematics learning outcomes $^{4}$. One of them when studying mathematics, can be connected with other fields such as being associated with the Qur'an.

The Qur'an as the basic guideline for human life must have all aspects contained in it. Even in the Qur'an there is also mathematics which is mostly about numbers and conclusions. Not only in mathematics, in the field of chemistry there is also a paired concept. Pairs in atomic theory are pairs between positive and negative, large and small a mass, and close distance to the atomic nucleus ${ }^{5}$. The relationship between mathematics and the Qur'an can be found in several fields. The concept discussed in this study is the concept of pairs found in the Qur'an and in mathematics is the oddeven concept. Odd and even are different properties. In mathematics odd and even can be found in terms of numbers.

\footnotetext{
${ }^{1}$ Abdussakir and Rosimanidar, "Model Integrasi Matematika Dan Al-Quran Serta Praktik Pembelajarannya," in Build a Competitive and Intellectual Young Mathematician Through Mathematics Competition and Integrating Islamic Values in Mathematics Learning (HMJ Pendidikan Matematika IAIN Bukittinggi, 2017).

${ }^{2}$ Mutijah, "Model Integrasi Matematika Dengan Nilai-Nilai Islam Dan Kearifan Lokal Budaya Dalam Pembelajaran Matematika," Jurnal Pendidikan Matematika 1, no. 2 (2018).

${ }^{3}$ Tundung Memolo, "Mengaitkan Aspek Materi Prasyarat Dalam Soal Eksplorasi Olimpiade Guru Nasional Matematika SMP Tahun 2017," in KNPMP III (Program Studi Pendidikan Matematika FKIP UMS, 2018).

${ }^{4}$ Anita Purnama Putri, Nursalam, and Sri Sulasteri, "Pengaruh Penguasaan Materi Prasyarat Terhadap Hasil Belajar Matematika Siswa Kelas VIII SMPN 1 Sinjai Timur," MaPan: Jurnal Matematika Dan Pembelajaran 2, no. 1 (2014).

${ }^{5}$ Muhammad Syahrul Kahar, "Kajian Atom Dalam Penciptaan Berpasangan," S P E K T R A Jurnal Kajian Pendidikan Sains 3, no. 1 (2017).
} 
Even numbers are denoted by $\mathrm{n}$ and odd numbers by $\mathrm{n}+1$. Giving this symbol as a differentiator from even and odd numbers. Regarding even and odd pairs, they are alternating numbers. However, not all even and odd pairs can be directly matched, they must go through several stages and categories in order to be paired ${ }^{6}$. Then will be presented some paired relationships between mathematics and the Qur'an that are interrelated with each other.

Previous research that discusses the relationship between the Qur'an and mathematics is about the interrelationship of the prayer movement, prayer is the core of acknowledging monotheism to Allah SWT as Al-Ahad and faith in Al-Unseen ${ }^{7}$. In addition, there is a change in views on Mathematics and Islam which were previously seen as separate things into something that is interrelated with each other ${ }^{8}$. There is an interconnection of angles in the Qur'an, where there are interconnections in every science, especially the angle with the Qur'an in many aspects and the point of view in this research can be said that basically there is no separation between the Qur'an and other sciences 9 . Some of the literature above has resulted in research showing the relationship between the Qur'an and mathematics, and in this study it is described more broadly about the integration between the two.

The method in this study uses a qualitative method. Qualitative research analyzes qualitative data, one of which is in the form of narration or sentences. According to Gogdan and Guba, a qualitative approach is a research procedure that produces descriptive data (data collected in the form of words, pictures, and not numbers $)^{10}$. While the type of research that researchers use is library research. In library research, there is a relationship between research objects obtained through library activities. Good research must start from reality or something real, the reality of the problem is clear ${ }^{11}$. This study was conducted with a qualitative approach and is a library research that was carried out simultaneously ${ }^{12}$. Literature research is an attempt at the method, namely by integrating mathematics with verses from the Qur'an.

\footnotetext{
${ }^{6}$ Yulianus Kantus, Anita Kurnia Rachman, and Artifa Sorraya, “Analisis Nilai Moral Dalam Novel Ganjil Genap Karya Almira Bastari,” in Peran Bahasa Dan Sastra Dalam Penguatan Karakter Bangsa (Prosiding Seminar Nasional Sastra, Lingua, Dan Pembelajarannya (Salinga), 2021).

7 Tomi Tristono and Zuhrotul Rumanah, "Studi Tentang Konsep Akar Karakteristik Pada Gerakan Spesifik Shalat," Profetika, Jurnal Studi Islam 21, no. 2 (2020): 231-44.

8 Febriarsita Eka Sasmita, "Eksplorasi Al-Quran Surah An-Nisaa Dalam Mentransformasi Matematika SD Yang Penuh Nilai," JPGSD6, no. 4 (2018).

${ }^{9}$ Iit Yulista, "Interkoneksi Matematika Pada Materi Sudut Dalam Al-Qur'an" (Universitas Islam Negeri Raden Intan Lampung, 2018).

${ }^{10}$ Endang Komara, Penelitian Tindakan Kelas Dan Profesionalisme Guru(Bandung: Refika Aditama, 2012).

${ }^{11}$ Ibrahim, Metodologi Penelitian Kualitatif(Bandung: Alfabeta, 2015).

12 Muthoifin, "Shariah Hotel And Mission Religion In Surakarta Indonesia," Humanities \& Social Sciences Reviews 7, no. 4 (2019): 973-979.
} 


\section{Islamic View of Education}

One of the verses in the Qur'an in Surah Ali Imran verse 65 which means "do you not think?" very familiar to the ears of the listeners (readers). The word is often heard when listening to lectures, or also often read by readers of the Qur'an. The sentence is a whip for humans to use their minds to finish or do something. Everything before acting must be thought out so as to obtain the best solution. Thinking is also synonymous with someone who must always learn. Students are accustomed to facing challenges and have the ability to solve problems ${ }^{13}$. Learn to change his life in order to get a better life. No wonder why Islam recommends learning from birth to death, because this is a form of practice against the verses of the Qur'an and its own benefits for those who practice it.

The easiest way to learn is to join the world of teaching and learning. One of the characteristics of formal learning is that education takes place in a classroom that is intentional ${ }^{14}$. In that place there are teachers who will teach, provide experience and knowledge in order to provide insight into knowledge for the future of students. Learning can also be done independently, of course this is more difficult because there is no one to accompany it like a teacher, because the existence of the teacher is limited $^{15}$. What can be done is to learn from someone's experience. Modify the information that has been obtained by using the mind. By thinking it will be able to change the future and is usually called education.

Education is the process of developing self-potential through conscious efforts that have been planned to the maximum extent possible in the learning process and are realized through learning activities ${ }^{16}$. The development of this potential is to improve a better personality, be able to control oneself, have competent intelligence, have good morals, have religious spiritual strength and skills needed by himself and the environment, nation, state and religion. Education is providing guidance and leading consciously carried out by an educator to his students so as to cause physical and spiritual development towards a charming personality ${ }^{17}$. Education in the sense used here, is a process or an activity which is directed at producing desirable changes in the behavior of human being ${ }^{18}$.

\footnotetext{
${ }^{13}$ Eny Sulistiani and Masrukan, "Pentingnya Berpikir Kritis Dalam Pembelajaran Matematika Untuk Menghadapi Tantangan MEA," in Seminar Nasional Matematika X (Universitas Negeri Semarang, 2016).

${ }^{14}$ Ibrahim Bafadhol, "Lembaga Pendidikan Islam Di Indoesia," Jurnal Edukasi Islami Jurnal Pendidikan Islam 6, no. 11 (2017).

${ }^{15}$ Agus Miftakus Surur, "Standart Kinerja Pengajaran Dosen Pendidikan Matematik," Factor M2, no. 1 (2019).

${ }^{16}$ Agus Miftakus Surur, Ragam Strategi Pembelajaran Dilengkapi Dengan Evaluasi Formatif (Banten: CV. AA. Rizky, 2020).

${ }^{17}$ Ahmad D Marimba, Pengantar Filsafat Pendidikan (Bandung: Al Ma'arif, 2003).

${ }^{18}$ Frederick j. MC Donald, Educational Psychology (Tokyo: Overseas Publication 1TD, 1959).
} 
Education has two forms, namely formal education and non-formal education ${ }^{19}$. Substantially, education can help to develop human intellectual abilities, can increase the intelligence of the mind, and also which is no less important, namely being able to develop aspects of the human personality. Education is the main means of developing the personality of every human being ${ }^{20}$.

In general, education is an activity to develop human beings as a whole which includes both physical and spiritual aspects. All efforts and efforts to improve the intelligence of students related to efforts to increase intelligence, emotional intelligence, and spiritual tendencies. On the one hand, students' physical skills are honed more disciplined so that they have the ability or professional expertise to provide for their life in society. On the other hand, his skills must be maximized by providing benefits to the community, especially for himself and his family, and to achieve his life goals in this world and in the hereafter ${ }^{21}$.

Learning for Muslims is emphasized, even to the point that it is mandatory, so that they will become aware of something. With knowledge, Allah elevates the level of the knowledgeable person. The path to heaven will be facilitated and the most important thing is that with knowledge humans will know their god, namely Allah SWT and make humans closer to $\mathrm{Him}^{22}$. In fact, it is the effort that a person makes that will make him change for the better or even for the worse. This is contained in the Qur'an Ar-Ra'd: 11.

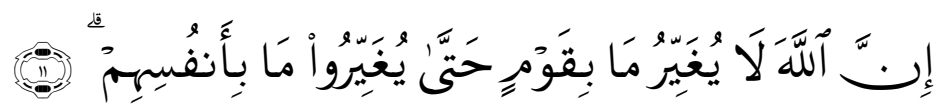

Translation: "Verily, Allah does not change the condition of a people until they change what is in themselves". (Ar-Ra'd: 11).

This proves that there are many invitations to continue learning that can be found in the Qur'an and also in the Hadith. Learning is a process of changing behavior and knowledge $\mathrm{e}^{23}$. This also makes the lecturers to invite them to always learn and keep learning.

Science is an important part to be fought for according to Islamic teachings. This is what supports the world of education to always improve its quality, so that educators and students become more aware of something. People who have knowledge will get a higher degree than people who are not / less educated, especially religious education, is highly respected. The Qur'an gives a higher position to people who are

\footnotetext{
${ }^{19}$ Abu Darda, "Integrasi Ilmu Dan Agama: Perkembangan Konseptual Di Indonesia," Jurnal AtTa’dib 10, no. 1 (2015): 33-46.

${ }^{20}$ Agus Miftakus Surur and Kharisma Nur Cholifah, "Good Governance Pada Kepengurusan Pondok Pesantren Putri Al-Amien,” Al-Tadzkiyyah: Jurnal Pendidikan Islam 9, no. 2 (2018): 261-74.

${ }^{21}$ Hasan Basri, Filsafat Pendidikan Islam (Bandung: Pustaka Setia, 2009).

${ }^{22}$ Rika Kumala Sari, "Kewajiban Belajar Dalam Tinjauan Hadits Rasulullah SAW," Sabilarrasyad 2, no. 1 (2017).

${ }^{23}$ Aprida Pane and Muhammad Darwis Dasopang, "Belajar Dan Pembelajaran," FITRAH Jurnal Kajian Ilmu-Ilmu Keislaman 3, no. 2 (2017).
} 
knowledgeable, in the form of degrees of glory and / or virtue, both in this world and in the hereafter. The knowledgeable people referred to here according to the Qur'an are lū al-'ilm, al-rāsikhūn fì al-'ilm, al-ālimūn, al-'ulamā, lū al-bāb, namely people who are knowledgeable as well as believers ${ }^{24}$. In society, the position of a teacher or ustadz gets more respect than ordinary people, this position is a prestigious position. In addition to religious teachers, people with general education, such as those with master's degrees, doctorates or even professors also have high positions in society. In addition to people who are knowledgeable, both general knowledge or religious knowledge, the position of government officials also has a high position, because as part of ulil amri, community leaders must have more skills. In the Qur'an, Allah SWT has also said about the position of an educated person, contained in the letter Al-Mujādilah verse 11:

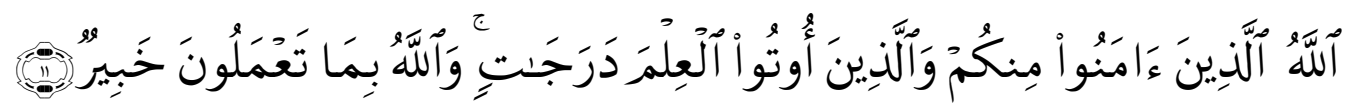

Translation: “... Allah will exalt those who believe among you and those who were given knowledge by several degrees. And Allah is aware of what you do." (Surat al-Mujādilah: 11).

From this it can be concluded that Islam really values a system called education and the people who are active in it. However, what needs to be considered is to realize together that, indirectly, Allah SWT has given two choices. First, to be noble, namely by being an educated person. Second, being an ordinary person who has the right to choose and must accept all the consequences.

The term education at this time is more popular by using the term tarbiyah. AtTarbiyah is a term that covers all educational activities. Tarbiyah is an effort that prepares individuals for a more systematic life in thinking, has sharp intuition, perfect ethics, is active in creativity, has tolerance for others, is competent in expressing spoken and written language, and has several skills ${ }^{25}$. While the other terms are part of tarbiyah activities. Thus, the term Islamic education is called Tarbiyah Islamiyah.

Learning anything is allowed as long as it is useful for oneself and others. It does not always require studying religion, but learning general knowledge can also make it easier for others. As well as deepening mathematics, it can be used in various fields, such as statistics which are widely used in economics and education, differential equations that can be used in mathematical modeling that can predict things such as the spread of epidemics/diseases, algebra and analysis to solve things in their field. To master the science of mathematics requires learning starting from the basics.

The basics of mathematics are even found in the Qur'an. Starting from those that are directly related to daily problems, or as a sign of the greatness of Allah the Creator.

\footnotetext{
${ }^{24}$ Surahman Amin and Ferry Muhammadsyah Siregar, “Ilmu Dan Orang Berilmu Dalam Al-Qur'an: Makna Etimologis, Klasifikasi, Dan Tafsirnya,” Empirisma 24, no. 1 (2015): 131-41.

${ }^{25}$ Muhammad Athiyah Al-Abrasyi, Ruh Al-Tarbiyat Wa Ta'lim, ed. Dar Al-Ahya' (Saudi arabiah, n.d.).
} 
In the Qur'an it has been explained, then humans are tasked with using their minds to uncover the secrets behind them.

\section{Odd and Even Numbers in the Qur'an}

Mathematics is a basic science that is either directly or indirectly needed by the community in everyday life ${ }^{26}$. Not forgetting the theory from Mathematician Ernest which states that Mathematics is a social constructivism, social constructivism aims to explain the nature of Mathematics to be widely understood. Mathematics in it will be in constant contact with numbers ${ }^{27}$.

Number is a mathematical concept used in counting and measurement. In contrast to the definition of numbers, which is a sign or symbol used to represent numbers. In mathematics there are several numbers that are often used, such as natural numbers, whole numbers, integers, rational numbers, real numbers and complex numbers. These numbers can be grouped again into new numbers, one of which is odd and even numbers.

Odd numbers are numbers which when divided by 2 will leave a remainder of 1 , while even numbers are numbers that are divisible by 2 . A short definition of odd numbers is a natural number that is not divisible by two or multiples thereof. An even number is a natural number which is divisible by two $^{28}$. The term even-odd has also been mentioned in the Qur'an, and this odd-even existence will continue so that it can make the reader happy. amazed by the existence of this odd-even number. Regarding even and odd, in the Qur'an it is stated clearly in the letter Al-Fajr verse 3:

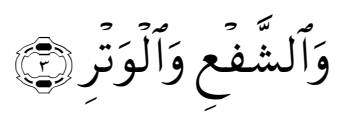

Translation: "and the even and the odd" (Al-Fajr: 3)

The meaning of this odd-even word has given several interpretations. Odd-even numbers are like numbers found in mathematics, so odd-even have the same position without being distinguished. The two have an interrelated relationship. The meaning of odd-even is also two things that are paired. Another example related to pairing is the existence of a man and a woman, so don't be sad if you haven't found a mate, a partner will definitely arrive, as in the letter Adh-Dhariyat, verse 49, namely

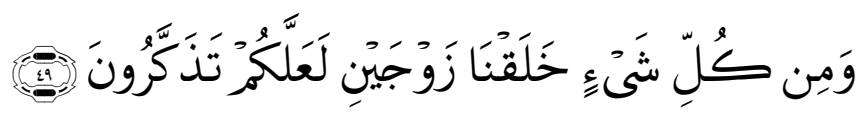

Translation: "And of all things We created two mates; perhaps you will remember". (Adh-Dhariyat: 49)

\footnotetext{
${ }^{26}$ A. H Fathani, Matematika: Hakikat \& Logika, ed. Ar-Ruzz Media (Yogyakarta, 2009).

${ }^{27}$ P Ernest, The Philosophy of Mathematics Education (London: Falmer, 1991).

${ }^{28}$ Dwi Safitri, "Pengembangan Media Find Me Pada Pelajaran Matematika Materi Bilangan Ganjil Genap Untuk Kelas II Sekolah Dasar,” JPGSD6, no. 5 (2018).
} 
In addition, pairs such as the existence of day and night, land and sea, dark and light, and others are the concept of pairing. Another thing that is also paired is the existence of a creator and the created. This is a pair of a creature that has its Creator.

The odd meaning can mean Allah SWT as the Lord of the Universe. No one can match Him which is stated in the letter Al-Ikhlas verses 1-4:

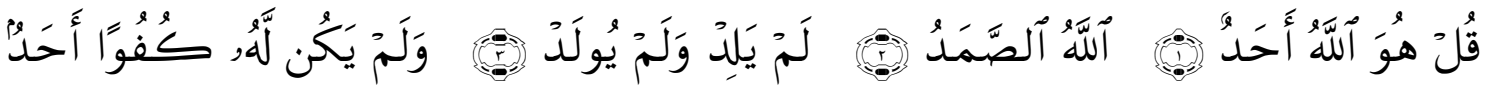

Translation: "1. Say, "He is Allah, [who is] One, 2. Allah, the Eternal Refuge. 3. He neither begets nor is born, 4. Nor is there to Him any equivalent." (QS. Al-Ikhlas:1-4)

Allah is self-sufficient, the first, the last, the greatest, the all knowing, and different from His creatures. The name of Allah is known as Asma'ul Husna, which means beautiful names. The name Asma'ul Husna is used to munajat, pray, ask only Allah SWT as in Surah Al-A'raf verse 180

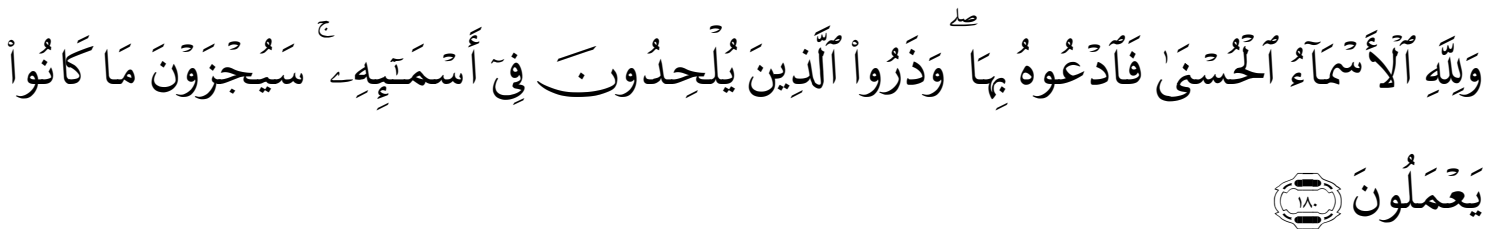

Translation: "Asma-ul-husna belongs only to Allah, so ask Him by mentioning Asmaul-Husna and leave those who deviate from the truth in (mentioning) His names. Later they will be rewarded for what they have done" (Al-A'raf: 180).

The beautiful names in Asma'ul Husna are highly recommended by mankind as His creatures to ask and pray to Him, because only Allah SWT worships, surrenders, and submits, also asks and pleads only to Him, as in the letter Al-Fatihah verse 5

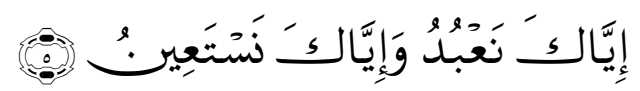

Translation: "It is You we worship and You we ask for help". (Al-Fatihah: 5)

From this explanation, the relationship between the Creator and creatures is very close. Furthermore, from this it is implied that there is a relationship and relationship between odd-even.

In addition, odd is also mentioned in another verse, which specifically mentions the number 7, of which 7 is an odd number, namely in the letter Al-Hijr verse 87

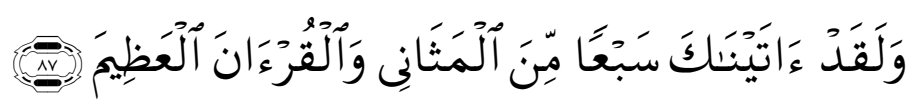

Translation: "And We have certainly given you, [O Muhammad], seven of the often repeated [verses] and the great Qur'an". (Al-Hijr: 87) 
The 7 verses that are often repeated are Surah Al-Fatihah. The letter becomes obligatory to read when establishing the five daily prayers which are obligatory for every Muslim. A day and night at least Muslims by establishing fardhu prayers then have read Al-Fatihah's letter repeatedly 17 times.

Mathematics, in using numbers is often used in counting. Math full of calculations $^{29}$. Counting anything related to the activities and activities of human life. This matter about counting is also contained in the Qur'an. Allah Himself also mentions that Himself also performs calculation activities. It is so important in doing calculations that nothing is arbitrary in deeds and actions. About this is found in the letter Al-Jinn verse 28.

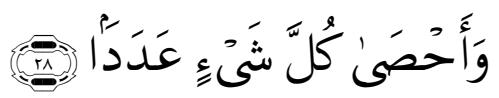

Translation: "He counted everything one by one". (Al-Jinn: 28)

From the verse above, it can be further observed that Surah Al-Jinn is a letter in the 72 nd order, and if the numbers 72 and 28 are added up, each number will be obtained.

$7+2+2+8=19$

From the results of these numbers, namely 72, 28 and 19, it can be seen that there is an even-odd relationship, odd there is one number, namely 19 and even there are two numbers, namely 72 and 28. Furthermore 19 is a prime number in the order of 8. So 8 and 19 is a pair of odd and even numbers.

The number 19 has many advantages. Rashad Khalifa proves the number 19 formula in the Qur'an with various facts and calculations. There are two variants of evidence submitted, namely the simple facts (simple evidence) and the intricate facts (complicated evidence) ${ }^{30}$. The number 19 can also be identified with the first verse of the Qur'an, the first verse of the Surah that is repeated. The verse is lafadz Basmalah. On the basmalah lafadz, consists of 19 letters of which the number 19 has many features, some of which will be presented as follows.

The word Ar-Rohman in the Qur'an is mentioned 57 times where 57 is a multiple of 19. In addition, the word Ar-Rahim is mentioned 114 times, of which 114 is also a multiple of 19. If 57 is a multiple of 3 of 19 and 114 is a multiple of 19. multiples of 6 of 19 , then the relationship between 3 and 6 there is an odd-even relationship.

The first surah that was revealed was Surah Al-Alaq verses $1-5$. In the verse above there are 19 words, and of the 19 words, they are composed of 76 letters. 19 and 76 become the next odd-even pair. It doesn't stop there, 76 is the result of multiplying $19 \times 4$, is a product of 19 , and 19 and 4 are odd-even pairs as well.

In another verse, namely in the letter Al-Muddaththir verse 30

\footnotetext{
${ }^{29}$ Ejen Jenal Mutaqin, “Analisis Learning Trajectory Matematis Dalam Konsep Perkalian Bilangan Cacah Di Kelas Rendah Sekolah Dasar," Dwijacendekia: Jurnal Riset Pedagogik 1, no. 1 (2017).

${ }^{30}$ Muhammad Akrom Adabi, "Alquran Dan Rahasia Angka: Kajian Kitab Tafsir Karya Abu Zahra Al-Najdi," Diya Al-Afkar 7, no. 2 (2019): 352-63.
} 


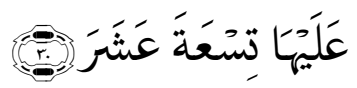

Translation: “And on it are nineteen (guardian angels)". (Al-Muddaththir: 30)

and Surah Al-Haqqah verse 17

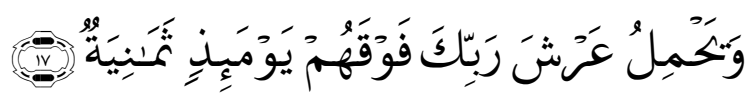

Translation: "And on that day eight angels will lift the Throne of your Lord above them". (Al-Haqqah: 17)

From the two verses above it says that there are 19 angels and the other verse mentions 8 angels. The special 19 continues and there is an odd-even relationship. Furthermore, Al-Muddaththir is the 74th letter and Al-Haqqah is the 69th letter, if the numbers of the letters and verses are added up, it is obtained

$74+30+69+17=190$

190 is a multiple of 19.190 is the product of $190=19 \times 10$. The numbers 19 and 10 are odd-even pairs.

In general, odd-even relationships can still be found, including the number of juz in the Qur'an as many as 30 juz, and 30 is the result of $30=5 \times 6,5$ and 6 are oddeven pairs. The number of letters in the Qur'an is $114,114=6 \times 19,6$ and 19 are oddeven pairs. The number of verses in the Qur'an is 6236, which can be obtained from $6236=1559 \times 4,4$ and 1559 are odd-even pairs.

The number of letters is 114 , when added up from $1+2+3+\ldots+113+114=$ 6555 , which 6555 is a multiple of 19 . Consider 6555 and 6236. If these numbers are added up, we get

$6+5+5+5+6+2+3+6=38$.

38 is a multiple of 19.38 is the product of $19 \times 2$ and 19 and 2 are odd-even pairs. And to close this section, 38 is the number of letters in the Shahadah sentence.

\section{The Concept of Angles in the Qur'an}

An angle is an image formed by two rays that are sides, sharing the same endpoint at the vertex/vetex. Regarding the angle, further study is needed because it shows the need for further observations with improvements ${ }^{31}$. Angles range from 0 degrees to 360 degrees. The degree symbol uses the number 0 as a power, which is " 0 ", so that the writing of 0 degrees becomes $0^{0}$ and 360 degrees becomes $360^{\circ}$. The term angle can also be found in the concepts of flat shapes and spatial shapes.

In addition, angles can also be found in verses of the Qur'an. In the Qur'an the relationship of angles is not conveyed directly, but by using the term cardinal directions, the verse is contained in the letter al-Baqarah verse 142

\footnotetext{
${ }^{31}$ Irpan Saripudin, Kutut Suryopratomo, and Andang Widi Harto, "Pengaruh Sudut Peletakan Dan Sudut Fase Pada Pipa Bersirip Terhadap Penurunan Tekanan,” Teknofisika 3, no. 1 (2014).
} 


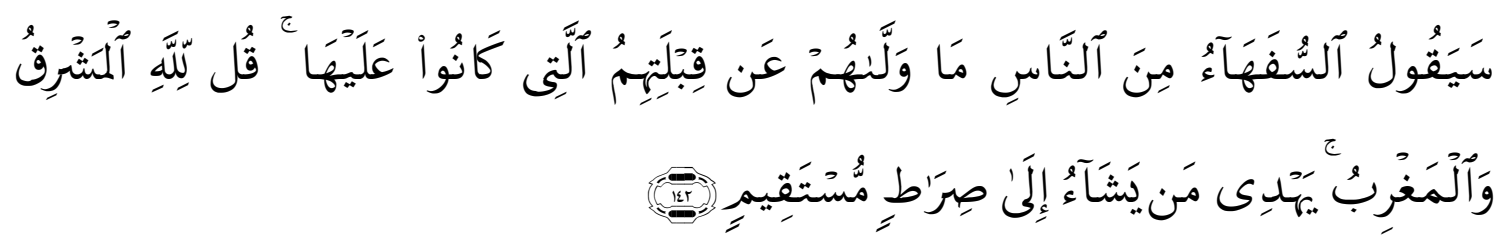

Translation: "People who lack sense among humans will say: "What turned them (Muslims) away from their Qibla (Baitul Maqdis) to which they had previously oriented?" Say: "To Allah belongs the east and the west; He guides whom He wills to a straight path." (Al-Baqarah: 142)

The above verse contains a word which means to turn away. In everyday terms it is usually referred to as changing 1800 . This shows if the verse contains an angle element. Another verse that contains a connection with angles is Surah Ar-Rahman verse 17 and Surah Yasin verse 40

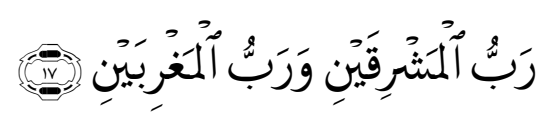

Translation: "The Lord who preserves the two places where the sun rises and the Lord who preserves the two places where it sets". (Ar-Rohman: 17)

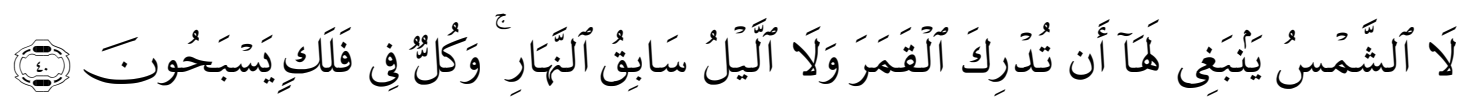

Translation: "It is not possible for the sun to find the moon and the night cannot precede the day. And each one circulates in its orbit". (Yasin: 40).

And there are still several verses that mention its relationship with angles, including:

1. Angle $0^{0}$

As in the letter Al-Ma'un verse 5 which states that people who are negligent in their prayers

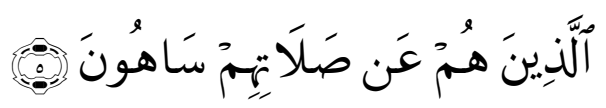

Translation: "[But] who are heedless of their prayer" - (Al-Ma'un: 5)

This can be interpreted that people who do not remember and do not worship Allah SWT, so it is likened to a $0^{0}$ angle who does not wake up at all to worship his Lord.

2. Angle $45^{0}$

In Surah Al-A'raf verse 26 it is stated that the signs of Allah's greatness have been shown to His servants

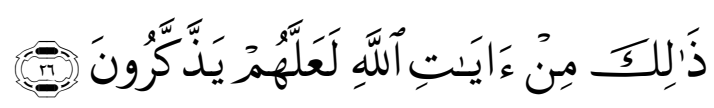

Translation: “...Those are some of the signs of Allah's power, hopefully they will always remember". (Al-A'raf: 26) 
This shows that only some are known and some are unknown to humans. Partially identical to the angle of $45^{\circ}$.

3. Angle $90^{\circ}$

Surah Al-Baqarah verse 125 states that the Maqam Ibrahim is allowed to be used as a place of worship or prayer

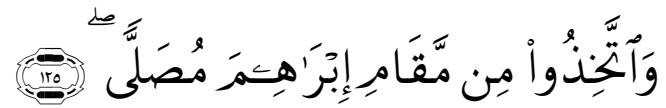

Translation: “...And make part of Ibrahim's station a place of prayer”. (AlBaqarah: 125)

Prayer activity is standing and perpendicular to the ground (place of prayer), so that it forms an angle of $90^{\circ}$.

\section{Value of Phi in Thowaf and Kaaba}

Tawaf is one of the pillars of Hajj, even more than that, Tawaf is a separate worship that is prescribed to do it every time. The most important thing about Tawaf is the opening and closing of the Hajj ${ }^{32}$. Phi is a number that is usually used in circles. Phi has 2 types, namely phi $=3.14$ and also phi $=22 / 7$. However, in more detail, phi is an example of a non-repeating number. The value of 3.14 is the result of rounding so that it is easy to calculate. $3.142857142857143 \ldots$ the value on the side that shows the value of phi with 15 digit numbers, and this number can still extend without repeating the numbers regularly. Regularly repeating decimal numbers can be converted into fractional form, such as the number $0.3333333 \ldots$ can be determined as a fraction, by for example

$$
\begin{array}{ll}
\mathrm{x} & =0.33333333333 \ldots \\
10 \mathrm{x} & =3.333333333333 \ldots \\
10 \mathrm{x}-\mathrm{x} & =3.33333333333 \ldots-0.33333333333 \ldots \\
9 \mathrm{x} & =3 \\
\mathrm{x} & =3 / 9 \\
& =1 / 3
\end{array}
$$

So $0.33333333333 \ldots \ldots \ldots=1 / 3$

A circle has several elements, including diameter, radius, arc, chord, segment, area, and circumference. In this section the elements used are diameter and circumference. The diameter is a straight line that connects the sides of the circle through the center of the circle. While the circumference is a line from the edge of a flat shape.

\footnotetext{
${ }^{32}$ May Dedu, "Hukum Ibadah Thawaf Bagi Wanita Haidh Menurut Imam Ibnu Mas'ud Al-Kasani AlHanafy,” Syntax Literate: Jurnal Ilmiah Indonesia 4, no. 5 (2019).
} 


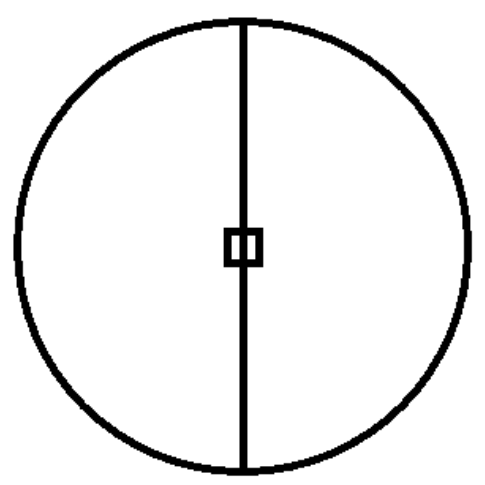

Figure 1. A circle with a diameter with a square center

Worship that must be done daily is prayer. Prayer five times a day and night must be done as long as the body is still able to perform it consciously. The five daily prayers consist of Fajr, Dhuhur, Asr, Maghrib and Isha prayers. Each has a rak'ah, respectively, namely 2, 4, 4, 3 and 4. So that Muslims in a day and night must pray 17 cycles. If the number of each raka'at is multiplied, it will be obtained $2 \times 4 \times 4 \times 3 \times 4=384$.

The sum of the rak'ahs and the product of the product yield the numbers 17 and 384 , and this is an odd-even number pair.

While the worship that can be done for those who can afford it is the pilgrimage which is carried out in Makkah Al-Mukarromah, Baitullah, where there is the Kaaba. In the flat wake of the Kaaba in accordance with the ritual is a circle, which is a place for Muslims to perform the thawaf worship, which is to surround the Kaaba. The trajectory around the Kaaba forms a circle with the center point of the Kaaba building itself. When performing thawaf, Muslims do it 7 times around the Kaaba. Thowaf itself is one of the pillars that must be done when someone performs the pilgrimage, and Hajj is one of the pillars of Islam that is highly recommended to be done if you already have the ability. Although the ability here must have a strong intention and also be cultivated.

Regarding the circle, the thowah trajectory that forms a circle, which can then be predicted how long the trajectory is. When performing thawaf with a certain distance from the Kaaba, it can use the formula for the circumference of the circle. Because in thawaf it is assumed that when circling the Kaaba with the same distance as the Kaaba, here we use diameter, so that the opposite sides have the same distance as the Kaaba, for phi itself using 22/7 because it is a rational number. The formula for the circumference of a circle using diameter is

$\begin{array}{ll}\text { Circumference } & =\text { thawaf }=\mathrm{T} \\ \text { Diameter } & =\mathrm{d} \\ \text { Phi } & =22 / 7 \\ \mathrm{~T} & =\mathrm{phi}^{*} \mathrm{~d} \\ & =22 / 7 * \mathrm{~d}\end{array}$


By moving the denominator 7 to the opposite side (left) we get the equation 7T $=22 \mathrm{~d} .7 \mathrm{~T}$ is synonymous with the number of thawaf that must be done when performing the pilgrimage. Hajj itself is one of the letters in the Qur'an called Al-Hajj. Al-Hajj is a letter in the $22 \mathrm{nd}$ sequence, and it is the same as the number in $22 \mathrm{~d}$. Is this a coincidence??

\section{The concept of FPB and KPK in the Qur'an}

Al-Quran has provided a clear and definite basis for regulating human life, both for non-Muslims and especially for Muslims. Everything is in the Quran. Business affairs, education, exemplary stories, government and other fields, and even the issue of distributing the inheritance of the deceased have also been regulated. People who die usually have assets left behind, and this becomes an inheritance that must be given to their heirs. Of course, you must first fulfill the dependents that are the responsibility of the deceased, such as debts, if you have debt, it means that the property must be paid on its debt first, funeral needs are also met first until the burial process. In addition, there is also the possibility that wills must also be made first to be fulfilled before the property is distributed to the heirs. Islam has regulated the issue of inheritance contained in fiqh based on the Qur'an and Hadith called Fara'idh.

The problem of Fara'idh is the arrangement of inheritance left by people who died to their heirs after fulfilling their debts in accordance with applicable regulations. The problem of Fara'idh is found in the verse of the Qur'an in the letter An-Nisa verses 11,12 and 176.

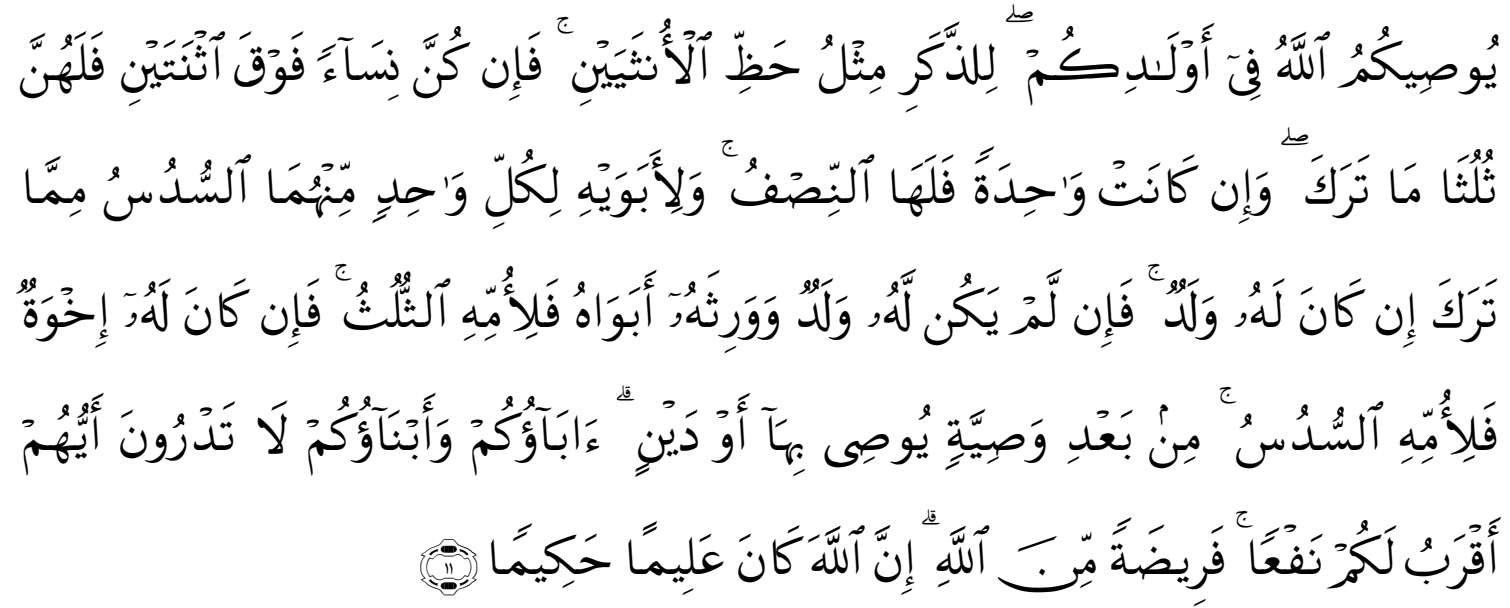

Translation: "Allah prescribes for you about (the division of inheritance for) your children. Namely: the share of a son is equal to the share of two daughters; and if the children are all girls more than two, then for them two thirds of the property left behind; If there is only one daughter, then she gets half of the property. And for two parents, for each one-sixth of the property left behind, if the deceased has children; if the person who dies has no children and he is inherited by his parents (only), then his mother gets a third; If the deceased has several siblings, then the mother 
gets one-sixth. (The distributions mentioned above) after the will has been fulfilled or (and) after the debt has been paid. (About) your parents and your children, you do not know which of them is closer to (many) benefits to you. This is a decree from God. Verily Allah is Knowing and Wise". (An-Nisa: 11)

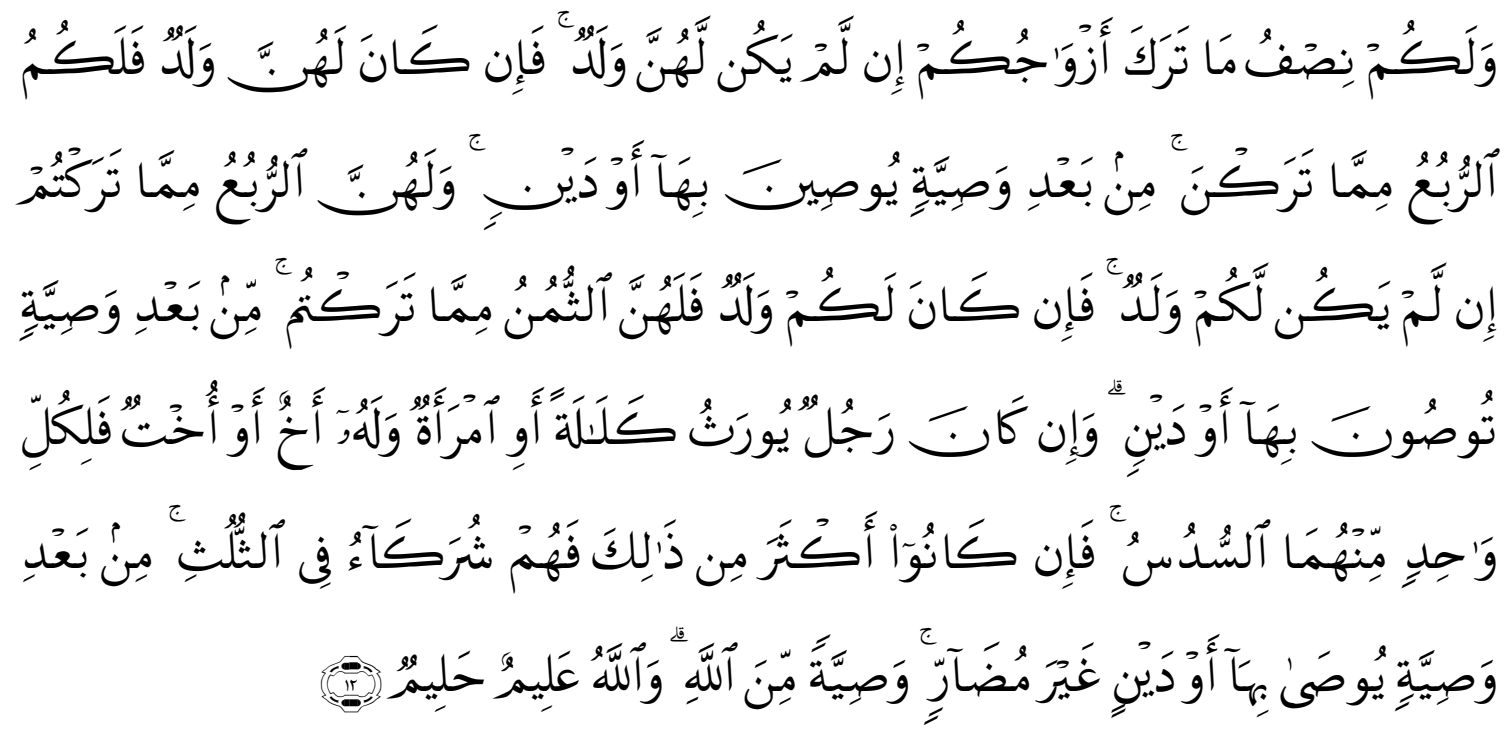

Translation: "And for you (husbands) half of the property left by your wives, if they do not have children. If your wives have children, then you will get a quarter of the property left by them after their will has been fulfilled or (and) the debt has been paid. Wives get a quarter of what you leave if you have no children. If you have children, then the wives get one-eighth of the property you left after fulfilling your will or (and) after paying your debts. If a person dies, both male and female, who does not leave a father and does not leave children, but has a brother (one mother only) or a sister (only one mother), then for each of the two types of brothers one sixth treasure. But if the mother's brothers are more than one, then they are partners in the third one, after fulfilling the will made by him or after paying the debt by not giving harm (to the heirs). (Allah established that as) the true Shari'ah from Allah, and Allah is All-Knowing, Most Forbearing. (An-Nisa: 12)

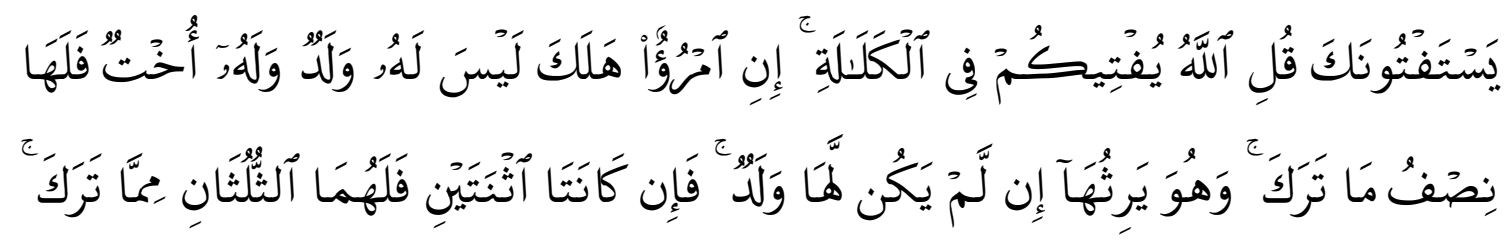




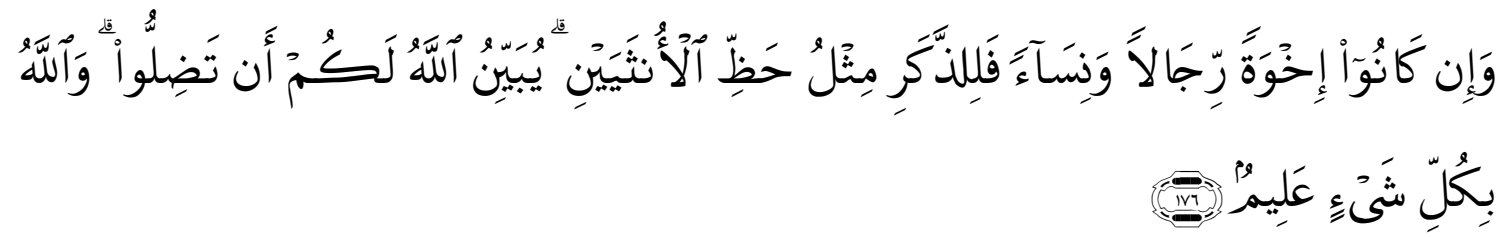

Translation: "They ask you for a fatwa (about losing). Say: "Allah gives you a fatwa regarding kalalah (ie): if a person dies, and he has no children and has a sister, then his sister will inherit one-half of the property he left behind, and his male brother will inherit (all his property). sister), if he has no children, but if there are two sisters, then for them two thirds of the property left by the deceased, and if they (the heirs consist of) brothers and sisters, then the share a brother as much as the share of two sisters. Allah explains (this law) to you, so that you do not go astray. And Allah is Knowing of all things. (An-Nisa: 176)

From the verses above, it is clear that the share and who are entitled to receive the inheritance are clearly stated. People who are entitled to receive inheritance are called Furudhul Muqoddaroh in accordance with the provisions. Separate parts can be concluded that there are 6 divisions

1. Part $1 / 2$ there are 5 relationships between heirs and the deceased, some of those who get property are daughters or husbands if the deceased wife has no children.

2. Part $1 / 4$ there are 5 relationships between the heirs and the deceased, some who get property are the husband's children if the wife who dies has children and the wife if the deceased husband has no children.

3. Section $1 / 8$ contains 1 relationship between the heir and the deceased, namely the wife if the deceased husband has children.

4. Part $2 / 3$ contains 4 heirs' relationship with the deceased, one of which is 2 or more daughters without a son.

5. Part $1 / 3$ there are 2 relationships between the heirs and the deceased, one of which is the mother if the child dies and the deceased has no children.

6. Part $1 / 6$ there are 7 relationships between the heirs and the deceased, one of which is the mother if the child dies and the deceased has a child.

Regarding the distribution of heirs above, there is a relationship between odd-even, namely odd is indicated by the number of people entitled to inherit and even is indicated by the division (group) of heirs. For the distribution of this inheritance there are fractions which will later be multiplied by the property left behind. To calculate it, you can use the KPK or GCF concepts learned in mathematics.

Case example 1

Pak Fulan died leaving his heirs with a wife, 2 daughters and 1 son. The assets he left after all of Mr. Fulan's dependents were fulfilled was IDR 50,000,000. What is the share of each heir? 
Answer

Known: inherited assets Rp. 80,000,000,-

: heirs of a wife, 2 daughters and 1 son

Asked : each part

Solution:

Wife gets $1 / 8$ share, because husband has children

2 daughters get a share $=$ sons, the property is divided into 4 parts: 1 share for the first daughter, 1 share for the second daughter and two parts for the son

$$
80,000,000 \times 1 / 8=10,000,000
$$

Remaining assets $80,000,000-10,000,000=70,000,000$

$$
70,000,000: 4=17,500,000
$$

So the mother gets an inheritance of Rp. 10,000,000,-

Each daughter gets an inheritance of IDR 17,500,000.

Boys get a share of Rp. 35.000.000,-

From the number of heirs who are included in Furudhul Muqoddaroh, there are 21 people who are entitled to receive inheritance, who are included in 6 divisions, so it is clear that 21 and 6 are odd-even pairs.

\section{Venn Diagram Concept in the Qur'an}

Diagram is a symbolic representation of information in the form of twodimensional geometry according to visualization techniques ${ }^{33}$. Diagrams can also be interpreted as simple images that use lines and symbols to describe the structure of certain objects in outline ${ }^{34}$. Diagrams can also be interpreted as certain symbols that can be used to explain the facilities, procedures and activities carried out in a system. Diagrams can also be referred to simply as presenting data in the form of images ${ }^{35}$.

While the Venn Diagram is a possible relationship between logic and hypotheses shown by a diagram on a group or group of subjects or objects ${ }^{36}$. Venn diagrams can also be used to show the relationship between sets and sets. The set itself is a clearly defined group of objects or objects ${ }^{37}$.

Example case 2

The set $\mathrm{A}$ is the set of even numbers less than 10 , so the elements are $2,4,6,8$. The set $\mathrm{B}$ is the set of square numbers less than 10 , so the elements are $1,4,9$. The set $\mathrm{C}$ is the set of multiples of 4 less than 10 , so the elements are 4,8 .

\footnotetext{
${ }^{33}$ Ating Somantri and Ali Muhidin, Aplikasi Statistika Dalam Penelitian., Sambas, 2006.

${ }^{34}$ Riduwan, Rumus Dan Data Analisis Statistika (Bandung: Alfabeta, 2005).

${ }^{35}$ Kadek Ayu Nastiti, Evaluasi Pembelajaran (Yogyakarta: Andi, 2017).

${ }^{36}$ Wikipedia, "Diagram Venn," 2021, id.m.wikipedia.org/wiki/Diagram_Venn.

${ }^{37}$ Amir Mahmud and Rizki Wahyu Yunian Putra, Himpunan: Teori Dan Contoh Soal (Malang: Ahli Media Press, 2020).
} 
If the universe is the set of natural numbers less than 10 , then the form of the Venn diagram is

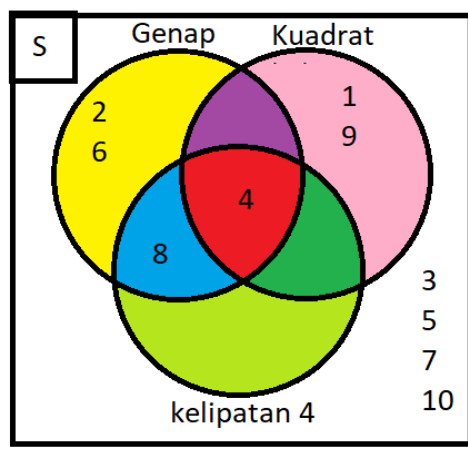

Figure 2. Venn diagram of the example case 2

The Qur'an also mentions the use of the concept of the Venn diagram in classifying certain groups. As in the following verse Surah Al-Hujurat verse 13

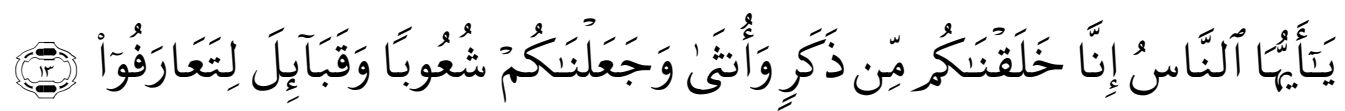

Translation: "O mankind, indeed We created you from a male and a female and made you into nations and tribes so that you may know one another". (AlHujurat: 13).

From the verse it is stated that humans were created from male and female groups. Then they were made into nations and tribes. The nation itself is a group of people who have the same identity and have the same purpose in life. Meanwhile, the tribe is a group of people whose members are based on common identification and often start from the similarity of descent. Both nations and tribes are examples of sets that can be made in the form of a Venn diagram.

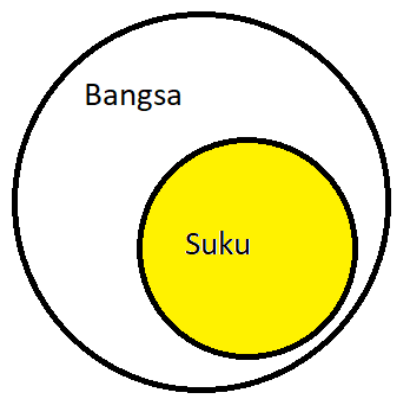

Figure 3. Venn diagram of the relationship between nations and tribes

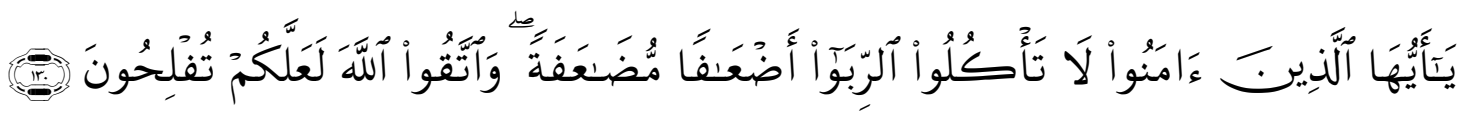

Translation: "O you who have believed, do not eat usury doubled] and fear Allah so that you may be successful". (Ali Imron: 130). 
From the letter Ali Imron verse 130 above can be formed into a Venn diagram of independent sets that are not related, because in the verse it is clearly stated by using the word "don't". The shape of the veen diagram is

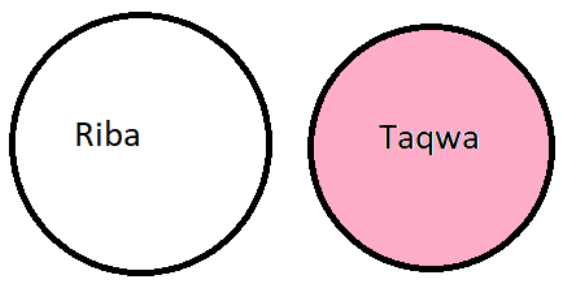

Figure 4. Venn diagram of the relationship between usury and taqwa

Translation: "O you who believe, do not eat each other's wealth in a false way, except by way of commerce which is carried out with mutual consent between you. And do not kill yourselves; Verily Allah is Most Merciful to you". (An-Nisa: 29).

Similar to the previous verse, the verse in Surah An-Nisa verse 29 can be made a Venn diagram of 3 groups, namely the group of people who eat property in vain, the group of people who commit suicide, and the group of consensual commerce. Can you make a venn diagram of the set in Surah An-Nisa verse 29?

Apart from the above verse, the use of sets and Venn diagrams can also be used in grouping Muslims. Muslims themselves can be grouped into several groups (associations), including the Muttaqin group, the Mukhsinin group, the Believer group, the Muslim group and the infidel group (Muslims who do not practice Islamic law). When converted into a venn diagram, it becomes

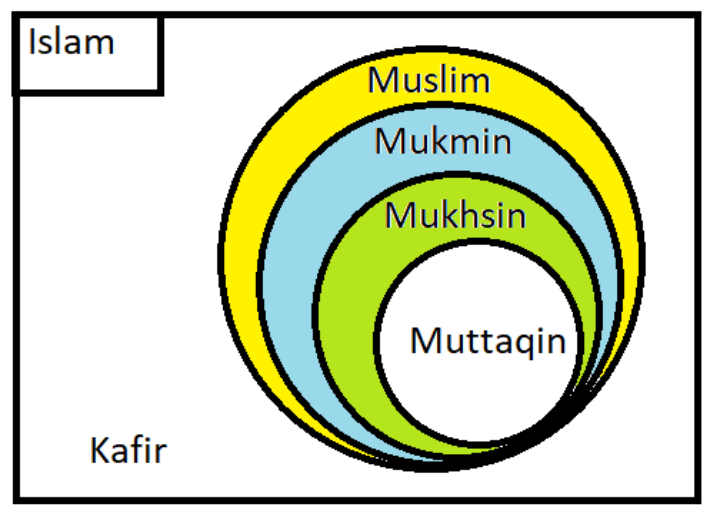

Figure 5. Venn diagram of Muslim groups

Diagrams are more about grouping. Starting from the creation of humans who are grouped into two groups, namely men and women. Meanwhile, Muamalah was discussed by Natural Uncertainty Contracts (NUC). NUC is a contract that is carried out not by agreeing on the nominal profit to be received but by agreeing on the profit sharing ratio to be received so that there is no certainty of the nominal value that will 
be received because it depends on business profits. There are 10 types of NUC that can be chosen in using the funds they have ${ }^{38}$. Regarding this, Allah only forbids usury and allows buying and selling, and this buying and selling can be represented by the 10 types mentioned in the NUC.

From the explanation above, in general, there is a relationship between grouping 1 and 2 of humans which are divided into 2 types, and 1 and 10 which are groupings between what is prohibited, namely usury and allowed NUC. These things provide reinforcement that there is an odd-even relationship.

\section{Conclusion}

Indeed, mathematics is the queen as well as the servant of the other sciences. As a queen because mathematical concepts are used in other fields, and as servants are used in helping solve problems in other fields. Mathematics is also guided by the Qur'an which is very systematic. Mathematics is not a new science created by humans, but has been created by Allah SWT as stated in the holy book Al-Qur'an.

Going a step further, the Qur'an is proven to be true with data that can be formulated using mathematics. This is to maintain the authenticity and purity of the Qur'an from time to time. Even though the times have changed, the verses in the Qur'an are not affected, because they have been maintained with systematic data.

Al-Quran contains science and sign. Science, the Qur'an was revealed as a guide for mankind in which there are signs of God's greatness which can be proven one of them by using mathematical concepts.

While the Sign gives a sign to humans to ensure faith that humans are only creatures of the God of the Universe, the Creator of all things. Maybe the sign given is supernatural which has not been proven true, but with the existence of science which is clearly proven as a whole, the author believes that the supernatural sign must also be proven. And Real and Unseen life is a pair that completes odd and even relationships.

\section{REFERENCES}

Abdussakir, and Rosimanidar. "Model Integrasi Matematika Dan Al-Quran Serta Praktik Pembelajarannya." In Build a Competitive and Intellectual Young Mathematician Through Mathematics Competition and Integrating Islamic Values in Mathematics Learning. HMJ Pendidikan Matematika IAIN Bukittinggi, 2017.

Adabi, Muhammad Akrom. "Alquran Dan Rahasia Angka: Kajian Kitab Tafsir Karya Abu Zahra Al-Najdi." Diya Al-Afkar 7, no. 2 (2019): 352-63.

Al-Abrasyi, Muhammad Athiyah. Ruh Al-Tarbiyat Wa Ta'lim. Edited by Dar Al-

${ }^{38}$ Nurul Ichsan, “Akad Bank Syariah,” Asy-Syir'ah: Jurnal Ilmu Syari'ah Dan Hukum 50, no. 2 (2016). 
Ahya'. Saudi arabiah, n.d.

Amin, Surahman, and Ferry Muhammadsyah Siregar. "Ilmu Dan Orang Berilmu Dalam Al-Qur'an: Makna Etimologis, Klasifikasi, Dan Tafsirnya." Empirisma 24, no. 1 (2015): 131-41.

Bafadhol, Ibrahim. "Lembaga Pendidikan Islam Di Indoesia." Jurnal Edukasi Islami Jurnal Pendidikan Islam 6, no. 11 (2017).

Basri, Hasan. Filsafat Pendidikan Islam. Bandung: Pustaka Setia, 2009.

Darda, Abu. "Integrasi Ilmu Dan Agama: Perkembangan Konseptual Di Indonesia." Jurnal At-Ta'dib 10, no. 1 (2015): 33-46.

Dedu, May. "Hukum Ibadah Thawaf Bagi Wanita Haidh Menurut Imam Ibnu Mas'ud Al-Kasani Al-Hanafy." Syntax Literate: Jurnal Ilmiah Indonesia 4, no. 5 (2019).

Donald, Frederick j. MC. Educational Psychology. Tokyo: Overseas Publication ITD, 1959.

Ernest, P. The Philosophy of Mathematics Education. London: Falmer, 1991.

Fathani, A. H. Matematika: Hakikat \& Logika. Edited by Ar-Ruzz Media. Yogyakarta, 2009.

Ibrahim. Metodologi Penelitian Kualitatif. Bandung: Alfabeta, 2015.

Ichsan, Nurul. “Akad Bank Syariah.” Asy-Syir'ah: Jurnal Ilmu Syari'ah Dan Hukum 50, no. 2 (2016).

Kahar, Muhammad Syahrul. "Kajian Atom Dalam Penciptaan Berpasangan." $S$ P E K T R A Jurnal Kajian Pendidikan Sains 3, no. 1 (2017).

Kantus, Yulianus, Anita Kurnia Rachman, and Artifa Sorraya. "Analisis Nilai Moral Dalam Novel Ganjil Genap Karya Almira Bastari.” In Peran Bahasa Dan Sastra Dalam Penguatan Karakter Bangsa. Prosiding Seminar Nasional Sastra, Lingua, Dan Pembelajarannya (Salinga), 2021.

Komara, Endang. Penelitian Tindakan Kelas Dan Profesionalisme Guru. Bandung: Refika Aditama, 2012.

Mahmud, Amir, and Rizki Wahyu Yunian Putra. Himpunan: Teori Dan Contoh Soal. Malang: Ahli Media Press, 2020.

Marimba, Ahmad D. Pengantar Filsafat Pendidikan. Bandung: Al Ma'arif, 2003.

Memolo, Tundung. "Mengaitkan Aspek Materi Prasyarat Dalam Soal Eksplorasi Olimpiade Guru Nasional Matematika SMP Tahun 2017." In KNPMP III. Program Studi Pendidikan Matematika FKIP UMS, 2018.

Mutaqin, Ejen Jenal. "Analisis Learning Trajectory Matematis Dalam Konsep Perkalian Bilangan Cacah Di Kelas Rendah Sekolah Dasar." Dwijacendekia: Jurnal Riset Pedagogik 1, no. 1 (2017).

Muthoifin. "Shariah Hotel And Mission Religion In Surakarta Indonesia." Humanities \& Social Sciences Reviews 7, no. 4 (2019): 973-979.

Mutijah. "Model Integrasi Matematika Dengan Nilai-Nilai Islam Dan Kearifan Lokal Budaya Dalam Pembelajaran Matematika." Jurnal Pendidikan Matematika 1, no. 2 (2018).

Nastiti, Kadek Ayu. Evaluasi Pembelajaran. Yogyakarta: Andi, 2017.

Pane, Aprida, and Muhammad Darwis Dasopang. "Belajar Dan Pembelajaran." FITRAH Jurnal Kajian Ilmu-Ilmu Keislaman 3, no. 2 (2017).

Putri, Anita Purnama, Nursalam, and Sri Sulasteri. "Pengaruh Penguasaan Materi Prasyarat Terhadap Hasil Belajar Matematika Siswa Kelas VIII SMPN 1 Sinjai Timur." MaPan Jurnal Matematika Dan Pembelajaran 2, no. 1 (2014). 
Riduwan. Rumus Dan Data Analisis Statistika. Bandung: Alfabeta, 2005.

Safitri, Dwi. "Pengembangan Media Find Me Pada Pelajaran Matematika Materi Bilangan Ganjil Genap Untuk Kelas II Sekolah Dasar.” JPGSD6, no. 5 (2018).

Sari, Rika Kumala. "Kewajiban Belajar Dalam Tinjauan Hadits Rasulullah SAW." Sabilarrasyad 2, no. 1 (2017).

Saripudin, Irpan, Kutut Suryopratomo, and Andang Widi Harto. "Pengaruh Sudut Peletakan Dan Sudut Fase Pada Pipa Bersirip Terhadap Penurunan Tekanan." Teknofisika 3, no. 1 (2014).

Sasmita, Febriarsita Eka. "Eksplorasi Al-Quran Surah An-Nisaa Dalam Mentransformasi Matematika SD Yang Penuh Nilai." JPGSD6, no. 4 (2018).

Somantri, Ating, and Ali Muhidin. Aplikasi Statistika Dalam Penelitian. Sambas, 2006.

Sulistiani, Eny, and Masrukan. "Pentingnya Berpikir Kritis Dalam Pembelajaran Matematika Untuk Menghadapi Tantangan MEA." In Seminar Nasional Matematika X. Universitas Negeri Semarang, 2016.

Surur, Agus Miftakus. Ragam Strategi Pembelajaran Dilengkapi Dengan Evaluasi Formatif. Banten: CV. AA. Rizky, 2020.

_. "Standart Kinerja Pengajaran Dosen Pendidikan Matematik." Factor M2, no. 1 (2019).

Surur, Agus Miftakus, and Kharisma Nur Cholifah. "Good Governance Pada Kepengurusan Pondok Pesantren Putri Al-Amien." Al-Tadzkiyyah: Jurnal Pendidikan Islam 9, no. 2 (2018): 261-74.

Tristono, Tomi, and Zuhrotul Rumanah. "Studi Tentang Konsep Akar Karakteristik Pada Gerakan Spesifik Shalat." Profetika, Jurnal Studi Islam 21, no. 2 (2020): 231-44.

Wikipedia. "Diagram Venn," 2021. id.m.wikipedia.org/wiki/Diagram_Venn.

Yulista, Iit. "Interkoneksi Matematika Pada Materi Sudut Dalam Al-Qur'an." Universitas Islam Negeri Raden Intan Lampung, 2018. 